\title{
Availability of Sports Facilities in Semarang City
}

\author{
Tommy Soenyoto ${ }^{1}$, Agus Darmawan ${ }^{2}$, Dwi Tiga Putri ${ }^{3}$, Adi $\mathrm{S}^{4}$ \\ \{tommysoenyoto@mail.unnes.ac.id ${ }^{1}$, agusputri12@mail.unnes.ac.id ${ }^{2}$, dwitgaputri@mail.unnes.ac.id ${ }^{3}$ \}
}

Universitas Negeri Semarang, Semarang Indonesia ${ }^{1,2,3}$

\begin{abstract}
The purpose of this study was to determine the availability of sports facilities and infrastructure in Semarang city. This research is a survey. Methods of data collection using observation, interviews, and documentation. The population used was 16 districts in Semarang city. The results showed that most of the infrastructure was badminton with $50.5 \%$, volleyball court with $15.3 \%$, open sports fields $8.1 \%$, swimming pool $7.8 \%$, martial arts gym $5.6 \%$, basketball court $4 \%$, tennis court $3,4 \%$, soccer field $2,2 \%$, futsal court $0,9 \%$, athletic stadium $0,9 \%$, billiard house $0,3 \%$, bowling arena $0,3 \%$, velodrome $0 \%$. The conclusion shows that the availability of infrastructure that is widely available in the city of Semarang is badminton, volleyball field, and open sports field infrastructure, while the infrastructure that is still lacking is a billiard house, a bowling arena, and a velodrome.
\end{abstract}

Keywords: sport, facilities, Semarang.

\section{Introduction}

Sport is exercise performed by one or more people who are a team or group. The definition of sport from the point of view of physiology is a series of regular and planned exercises that a person consciously does to improve his functional ability, in accordance with his goal of doing sports. [1,2]. Sport is one of the physical activities carried out with the intention of maintaining and maintaining the fitness of the human body. In its development, it can be done as an entertaining, fun activity or it can also be done with the aim of increasing achievement. Increasing public interest in sports is not matched by the quality and quantity of sports facilities [3]. Besides that, sport is a phenomenon in society and an inseparable part of life for humans on this earth. Sport which basically has a very big role in efforts to improve the quality of human resources for mental development and also yourself. A city / district / province that wants very fast and fast progress in various fields, and considers sports to be very important. The strategy for the use of sports must go through development planning in favor of the progress of sports as a whole. Comprehensive because sport has the potential to contain a passion and strength to build a passionate soul from a very long process of development itself $[4,5]$

In terms of juridical (law) according to Law no. 3 of 2005 sports are all systematic activities to encourage the development and development of physical, spiritual and social potential. Basically, sports have a very strategic role in efforts to establish the quality of human resources to build a city / district / province that wants rapid progress in various fields, even if it should not be merely a slogan to consider sport as an important thing. (6) Sports facilities and infrastructure are something that cannot be separated from one another in sports. Where between the two there is a common relationship. A facility is something that can be 
used and utilized in the implementation of sports or physical education activities. Meanwhile, infrastructure is something that simplifies or expedites tasks and has a relatively permanent nature $[7,8]$.

Sports infrastructure is a supporting resource consisting of all types of buildings / without buildings used for sports equipment. Good sports infrastructure can support community growth, especially in the field of improving the quality of human resources in the world of sports [9]. Sports facilities are a permanent form, both for indoor and outdoor spaces. For example: gymnasium (gymnasium), swimming pool, playing fields, and so on ". Sports facilities in it consist of facilities and infrastructure to support sports activities. The facility itself is one of the important elements that must be available in sports. [10] Overall sports facilities include physical and non-physical facilities. Physical sports facilities include infrastructure and physical facilities, including stadiums, arenas and fields for various sports. Meanwhile, non-physical sports facilities include non-physical infrastructure and facilities such as sports clubs / associations, trainers and sports teachers [11]. National Sports Standardization aims to ensure the quality of the implementation of the national sports system through the achievement of National Sports Standards (Government Regulation number 16 of 2007 Article 84) [12]. Regulation of the Minister of Youth and Sports Number 0445 of 2014 article 1 states that the Standard for Sports Infrastructure in the form of a Sports Building is a minimum criterion regarding various aspects related to the building and the environment around the building used for sports activities and / or organizing sports activities. The government through the Ministry of Youth and Sports issued a Sports Building Standardization in Indonesia which has the aim that each sports facility has the same standard of quality as well as safety and security criteria owned by the Sports Building because sports will involve large crowds. The scope of standards according to Permenpora No. 0445/2014 includes: 1) Typology of sports buildings. 2) Location. 3) Zones and circulation. 4) Arena. 5) Player facilities. 6) Match / Activity Management Room. 7) Media facilities. 8) Sports building management facilities. 9) Spectator Facilities. 10) Safety and security facilities. 11) Communication facilities (display board). 12) Building utilities. 13) Prevention of fire hazards. 14) Structure and materials [13]. Typically exclude from definition of a sport facility are the nature areas,and team owners have argued that sports facilities boost local economic activity; however, economic reasoning and empirical evidence suggest the opposite $[14,15]$.

\section{Methods}

This study used a survey research design. Data collection methods use observation, interviews, and documentation. The research places and locations are as many as 16 subdistricts in the city of Semarang which are used as research sites. The data analysis technique uses a data reduction system to present the data in the form of calculating the quantity as well as the quality of the facilities and infrastructure in the city of Semarang.

\section{Result and Discussion}

This research produces sports infrastructure data in the city of Semarang. 
Table 1. Volleyball Courts.

\begin{tabular}{lc}
\hline Sub Distric & Amount \\
\hline Semarang Tengah & 0 \\
Semarang Utara & 5 \\
Semarang Timur & 6 \\
Gayamsari & 4 \\
Genuk & 7 \\
Pedurungan & 24 \\
Semarang Selatan & 0 \\
Candisari & 6 \\
Gajahmungkur & 19 \\
Tembalang & 6 \\
Banyumanik & 36 \\
Gunungpati & 49 \\
Semarang Barat & 12 \\
Mijen & 18 \\
Ngaliyan & 11 \\
Tugu & 8 \\
\hline
\end{tabular}



Fig. 1. Volleyball Courts. 
Table 2. Basketball Courts.

\begin{tabular}{lc}
\hline Sub Distric & Amount \\
\hline Semarang Tengah & 13 \\
Semarang Utara & 3 \\
Semarang Timur & 1 \\
Gayamsari & 1 \\
Genuk & 3 \\
Pedurungan & 3 \\
Semarang Selatan & 2 \\
Candisari & 0 \\
Gajahmungkur & 6 \\
Tembalang & 0 \\
Banyumanik & 3 \\
Gunungpati & 7 \\
Semarang Barat & 5 \\
Mijen & 0 \\
Ngaliyan & 2 \\
Tugu & 2 \\
\hline
\end{tabular}

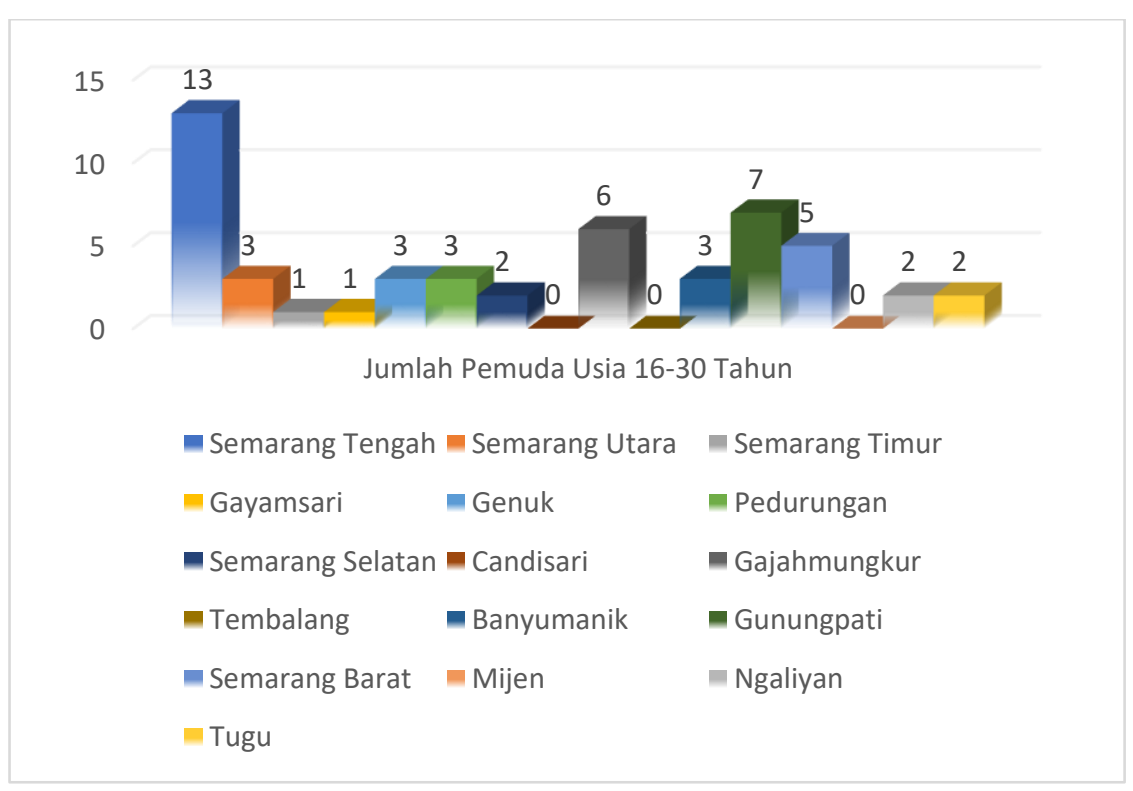

Fig. 2. Basketball Courts. 
Table 3. Tennis Courts.

\begin{tabular}{lc}
\hline Sub Distric & Amount \\
\hline Semarang Tengah & 2 \\
Semarang Utara & 0 \\
Semarang Timur & 1 \\
Gayamsari & 1 \\
Genuk & 1 \\
Pedurungan & 0 \\
Semarang Selatan & 3 \\
Candisari & 1 \\
Gajahmungkur & 4 \\
Tembalang & 3 \\
Banyumanik & 11 \\
Gunungpati & 0 \\
Semarang Barat & 2 \\
Mijen & 0 \\
Ngaliyan & 1 \\
Tugu & 0 \\
\hline
\end{tabular}

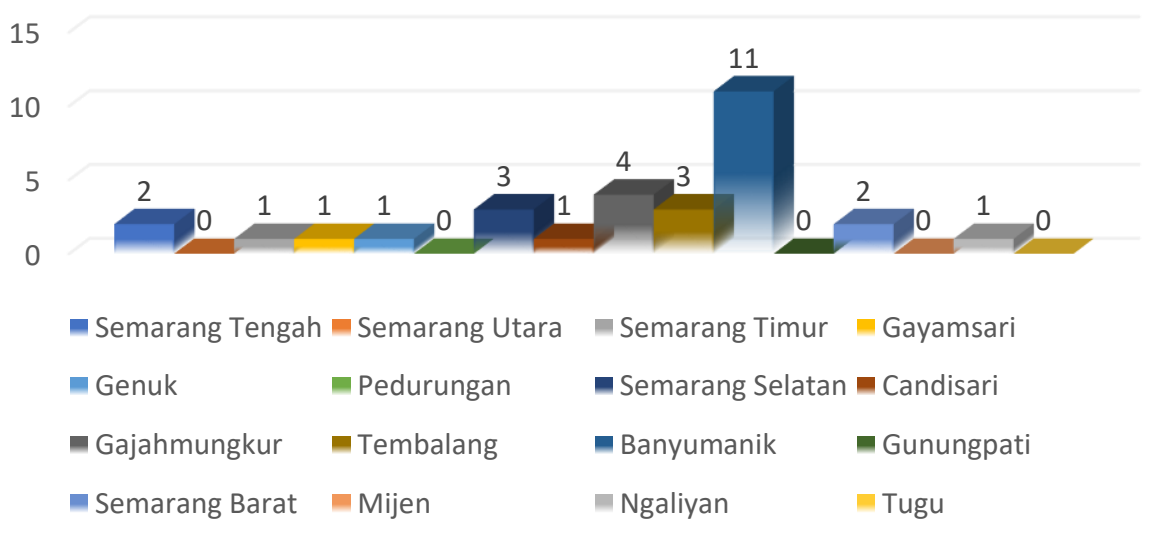

Fig. 3. Tennis Courts. 
Table 4. Futsal Fields.

\begin{tabular}{|c|c|}
\hline Sub Distric & Amount \\
\hline Semarang Tengah & 0 \\
\hline Semarang Utara & 4 \\
\hline Semarang Timur & 1 \\
\hline Gayamsari & 4 \\
\hline Genuk & 4 \\
\hline Pedurungan & 3 \\
\hline Semarang Selatan & 3 \\
\hline Candisari & 1 \\
\hline Gajahmungkur & 2 \\
\hline Tembalang & 1 \\
\hline Banyumanik & 5 \\
\hline Gunungpati & 0 \\
\hline Semarang Barat & 4 \\
\hline Mijen & 3 \\
\hline Ngaliyan & 2 \\
\hline Tugu & 2 \\
\hline $\begin{array}{llllllll}4 & & 4 & 4 & 3 & 3 & 1 \\
& & & & & & & \end{array}$ & $2 \quad 1 \stackrel{5}{2} \stackrel{4}{4}^{2} 32^{2} 2$ \\
\hline \multicolumn{2}{|c|}{ Jumlah Pemuda Usia 16-30 Tahun } \\
\hline ah $=$ Semarang Utara & Semarang Timur Gayamsari \\
\hline = Pedurungan & - Semarang Selatan $=$ Candisari \\
\hline - Tembalang & - Banyumanik \\
\hline t $=$ Mijen & Ngaliyan \\
\hline
\end{tabular}

Fig. 4. Futsal Fields.

Buildings for football sports activities, including facilities for spectators, both matches / competitions and for training.

Table 5. Football Stadiums.

\begin{tabular}{lc}
\hline Stadium Type & Amount \\
\hline Type A & 0 \\
Type B & 2 \\
Type C & 7 \\
\hline
\end{tabular}

Stadium type A is a football stadium with an audience capacity of 30,000-50,000 people, with a total of 8 running tracks for $400 \mathrm{~m}$ and 100/110 m running tracks. Stadium type B is a football stadium with an audience capacity of 1000-30,000 people, with a total of 6 or 8 running tracks for $400 \mathrm{~m}$ and $100 / 110 \mathrm{~m}$ running tracks. Type $\mathrm{C}$ stadium is a football stadium with an audience capacity of 500-10,000 people, with a total of 6 or 8 running tracks for 400 
$\mathrm{m}$ and 100/110 m running tracks. From the table above, it can be seen that the number of type a football stadiums is 0 , type $b$ is 2 and type $c$ is 7 .

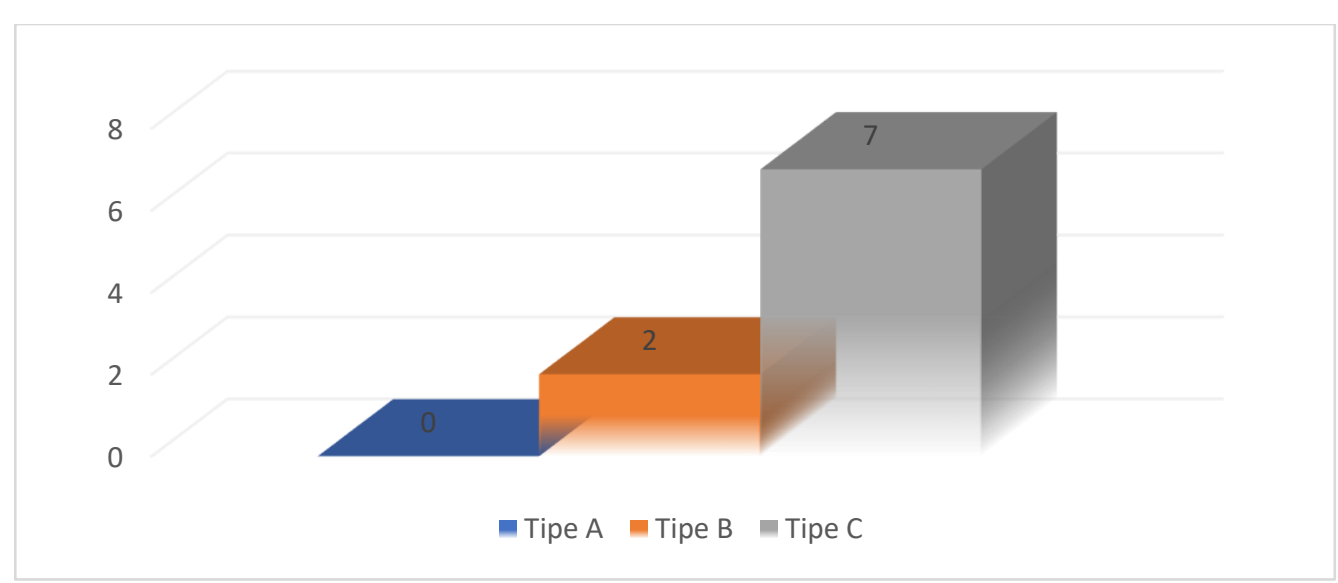

Fig. 5. Football Stadiums.

Buildings for athletic sports activities, including facilities for spectators, both matches / competitions and for training.

Table 6. Athletic Stadiums.

\begin{tabular}{lc}
\hline Stadium Type & Amount \\
\hline Type A & 0 \\
Type B & 0 \\
Type C & 3 \\
\hline
\end{tabular}

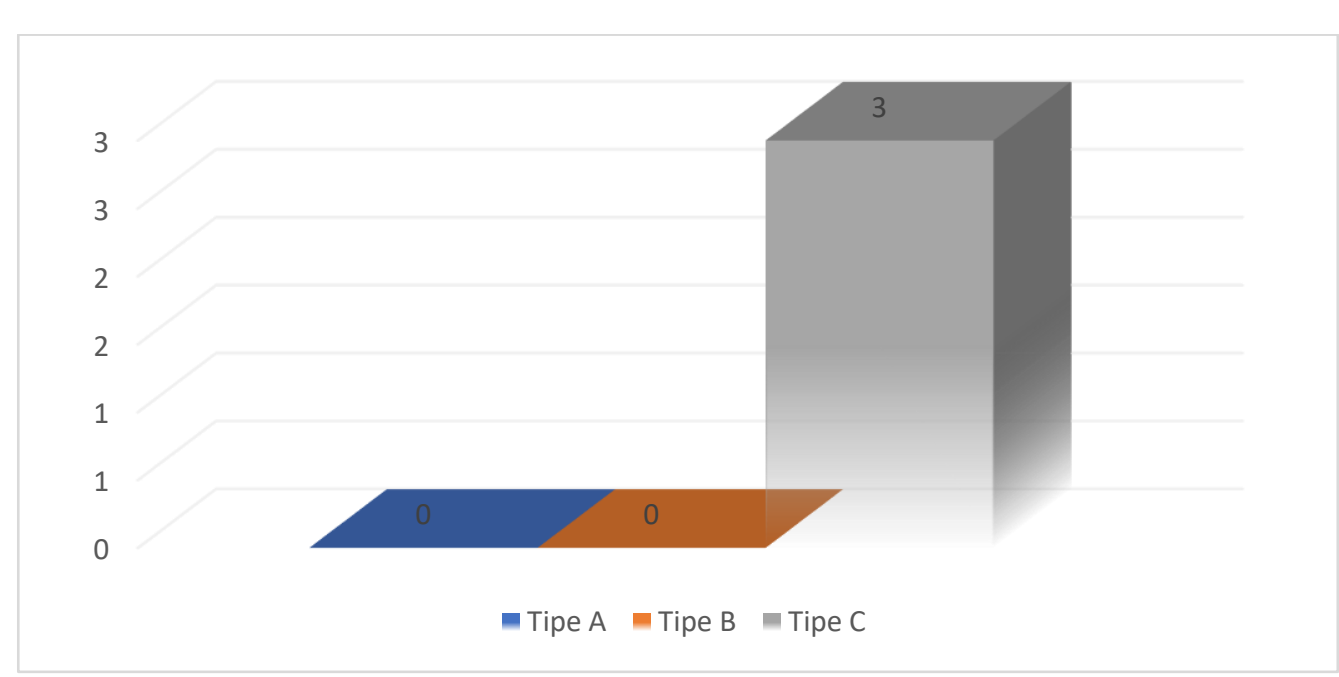

Fig. 6. Athletic Stadiums. 
Table 7. Badminton Court.

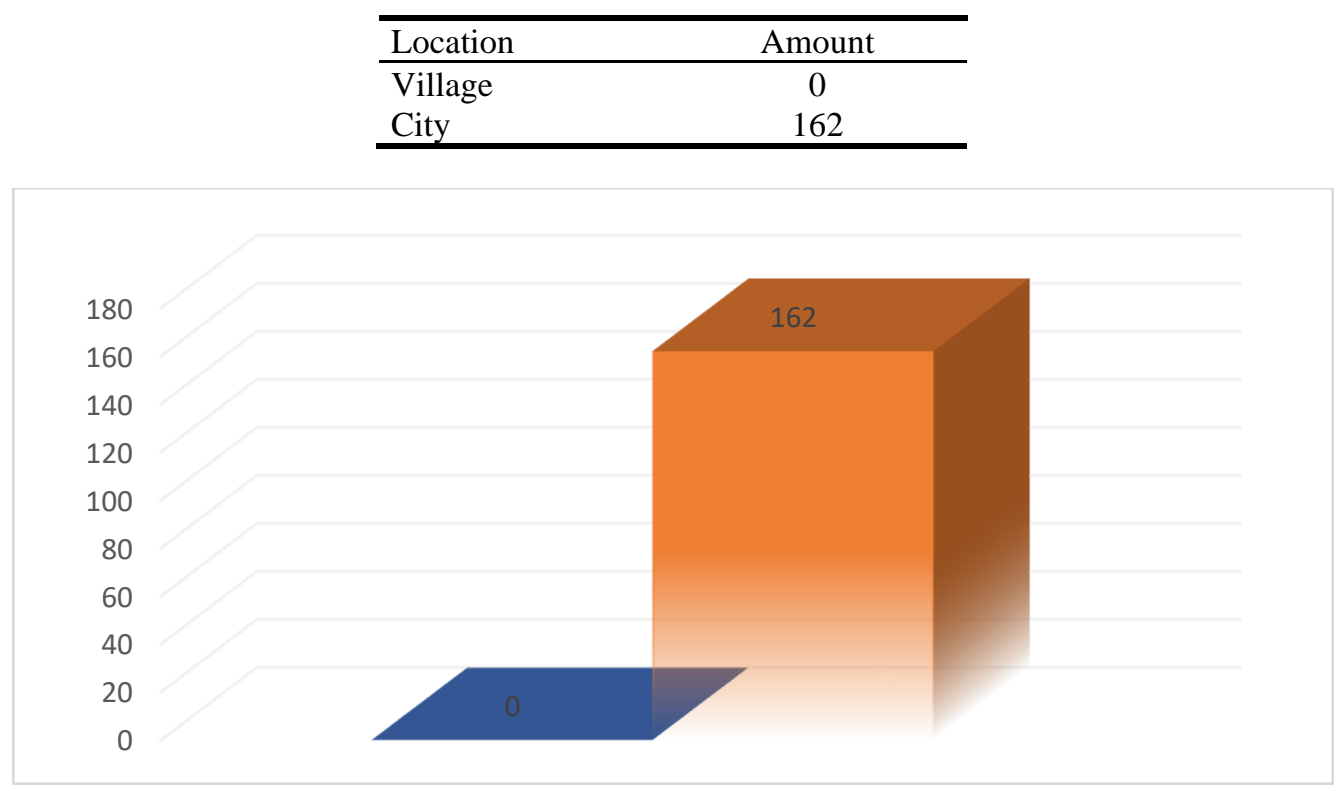

Fig. 7. Badminton Court

Based on the results of the study, it was found that the city of Semarang has adequate and complete facilities and infrastructure. The complete analysis is presented in accordance with table 8 .

Table 8. Sport Facilities.

\begin{tabular}{lccc}
\hline Sub Indicator & Ave & Min & Max \\
\hline Volleyball court & 13 & 0 & 49 \\
Basketball court & 3 & 0 & 13 \\
Tennis court & 2 & 0 & 11 \\
Lapangan Futsal & 2 & 0 & 5 \\
Football Stadium & 4 & 0 & 7 \\
Athletic Stadium & 3 & 0 & 3 \\
Badminton Field & 162 & 0 & 162 \\
\hline
\end{tabular}

In data above, you can see the sports infrastructure indicator with the volleyball field subindicator with an average of 13 with the lowest number of 0 in Central Semarang and South Semarang districts, while the highest number is 49 Gunungpati districts. Basketball court had an average of 3 with the lowest number of 0 in Candisari, Tembalang and Mijen districts, while the highest number was 13 districts of South Semarang. The average tennis court was 2 with the lowest number of 0 in North Semarang, Pedurungan, Gununpati and Mijen districts, while the highest number was 11 Banyumanik districts. The average futsal field is 2 with the lowest number of 0 in Central Semarang and Gunungpati districts, while the highest number is 5 in Banyumanik districts. The average football stadium is 4 with the lowest number of 0 in 
type a while the highest number is 7 in type c. Athletic stadiums with a mean of 3 have the lowest number of 0 in type a and b while the highest number is 3 in type $c$. The average badminton court is 1622 with the lowest number of 0 in rural areas, while the highest number is 162 in urban areas. The sports hall with a mean of 2, the lowest number is 0 in type a, while the highest number is 2 in type c. Billiards houses with a mean of 1 , the lowest number is 0 , while the highest number is 1 in Candisari, Gajahmungkur and Banyumanik. Open sports fields mean 9, the lowest is 0, Gayamsari, Candisari, West Semarang and the highest is 26, Genuk.

\section{Conclusion}

Based on the research results, it can be concluded that the city of Semarang has quite a lot of sports facilities, complete, and evenly distributed in 16 Districts. These facilities and infrastructure are put to good use by the people of Semarang City in carrying out sporting activities in the City of Semarang..

\section{References}

[1]. Purwanto DD. Definition Sport ans Physical Fitness. Downloaded from: http://www.slideshare.net/dimaswi/pengertian-olahraga-kebugaranjasmani. Accessed on 21 Februari 2012

[2]. Palar, C. M., Wongkar, D., \& Ticoalu, S. H. (2015). The benefits of aerobic exercise for human physical fitness. eBiomedik, 3(1).

[3]. Hasugian, H., \& Shidiq, A. N. (2012). Design and build creative industry information systems in the field of sports facilities rental. Semantik, 2(1).

[4]. Kristiyanto, Agus. 2012. Sports Development for People's Welfare and Nation's Glory. Surakarta: Yuma Pustaka.

[5]. Firdaus, M., \& Purnomo, A. M. I. (2015). Utilization of Selomangkleng Recreation Park (Klotok) as Community Sports Facilities and Infrastructure in Kediri City. Jurnal Sportif, 1(1), 81-99.

[6]. Constitution No. 32005 About the National Sports System

[7]. Soepartono, 2000. Sport Facilities. Departemen Pendidikan Nasional Direktorat Jendral Pendidikan Dasar dan Menengah Bagian Proyek Penataran Guru SLTP Setara D-III.

[8]. Junaedi, A. (2015). Survey on the Progress Level of Physical Education, Sports, and Health in Senior High Schools, Junior High Schools, and Public Schools in Gresik Regency. Jurnal pendidikan olahraga dan kesehatan, 3(3).

[9]. Irawan, R. (2017). Feasibility Study of Indoor Sports Facilities at FIK UNNES. Jurnal Penjakora, 4(1), 90-102.

[10]. Pratama, N. A. (2016). Analysis of Standardization of Sports Field Facilities at the Bahurekso Kendal Sports Center (Doctoral dissertation, Universitas Negeri Semarang).

[11]. Basuki, S. (2017). Student Participation in Sports Activities and Supporting Facilities at Lambung Mangkurat University. Multilateral Jurnal Pendidikan Jasmani dan Olahraga, 16(1).

[12]. Government regulations number 16, 2007

[13]. Regulation of the Minister of Youth and Sports Number 0445, 2014 
[14]. Fried, G., \& Kastel, M. (2020). Managing sport facilities. Human Kinetics.

[15]. Siegfried, John, J., and Andrew Zimbalist. 2000. "The Economics of Sports Facilities and Their Communities." Journal of Economic Perspectives, 14 (3): 95-114. Siegfried, John, J., and Andrew Zimbalist. 2000. "The Economics of Sports Facilities and Their Communities." Journal of Economic Perspectives, 14 (3): 95-114. 